\title{
Gaya Komunikasi Pemimpin Jemaat Gereja Every Nation Jakarta dalam Membangun Loyalitas Jemaat
}

\author{
Joedea Aris Theofilus, H. H. Daniel Tamburian \\ joedea.915160225@stu.untar.ac.id,danielt@fikom.untar.ac.id
}

Fakultas Ilmu Komunikasi Universitas Tarumanagara

\begin{abstract}
The leader of church congregation, has the role that is vital both in a church and a Christian community. A leader can give a huge impact in various aspects in the church as well the community he is leading. One of the things that needs to be highlighted in a leader is the communication style they use in conversing to his congregation. It is important to observe the communication style used as it could be a leader's advantage in building the congregation's loyalty. In this research, the writer is going to conduct a research regarding the communication style that is used by the leader of Every Nation Jakarta in terms of building congregation's loyalty. In this research, the writer is going to conduct a qualitative research along with case study method. The theory that assists this research is the theory of communication style that is further backed up by the theory of the leader's trait. The results of the research will reveal the communication style to the leader's trait of Ps Jahja Gani as the leader of the congregation in Every Nation Jakarta based on the interviewee's perspective, things that are done in achieving congregation's loyalty, as well as the interviewee's perspective of Ps Jahja Gani's leadership that has been deemed to fit both the congregation's situation and condition of Every Nation Jakarta.
\end{abstract}

Keywords: communication style, leader, loyalty, church.

\begin{abstract}
Abstrak
Pemimpin jemaat gereja, memiliki peranan yang sangat penting dalam suatu gereja maupun suatu komunitas rohani Kristen. Seorang pemimpin jemaat dapat memberikan pengaruh besar di berbagai aspek dalam gereja maupun komunitas yang ia pimpin. Salah satu hal yang perlu diperhatikan dari seorang pemimpin gereja adalah gaya komunikasi kepada para jemaatnya. Gaya komunikasi perlu diperhatikan, karena gaya komunikasi yang sesuai dan tepat dapatlah menjadi keunggulan bagi pemimpin gereja dalam membangun loyalitas jemaatnya. Pada penelitian ini, penulis akan meneliti gaya komunikasi pemimpin jemaat dari gereja Every Nation Jakarta dalam membangun loyalitas jemaatnya. Pendekatan penelitian yang digunakan pada penelitian ini adalah kualitatif dengan metode studi kasus. Teori yang membantu penelitian ini adalah teori gaya komunikasi, serta didukung juga dengan teori sifat pemimpin. Hasil dari temuan penelitian yang dilakukan, mengungkapkan gaya komunikasi, hingga sifat pemimpin dari Ps. Jahja Gani selaku pemimpin jemaat gereja Every Nation Jakarta berdasarkan sudut pandang para narasumber, hal - hal yang dilakukan dalam membangun loyalitas jemaat, serta pandangan para narasumber jemaat mengenai kepemimpinan Ps. Jahja Gani yang dinilai sudah tepat dan sesuai dengan situasi kondisi jemaat di gereja Every Nation Jakarta.
\end{abstract}

Kata Kunci: gaya komunikasi, pemimpin, loyalitas, gereja.

\section{Pendahuluan}

Agama sangatlah mengambil peran bagi kehidupan banyak individu serta kelompok masyarakat di Indonesia. Dalam setiap kelompok agama terutama Kristen, 
peran dari seorang pemimpin jemaat dinilai sangat penting, dikarenakan merekalah yang akan membawa arah, perkembangan, sampai perilaku yang akan terjadi di internal kelompok tersebut, pastilah berpengaruh dengan bagaimana perilaku maupun pembawaan pemimpinnya jemaatnya. Salah satu hal yang perlu dijaga oleh seorang pemimpin jemaat Kristen sewaktu mereka memimpin suatu gereja maupun komunitas Kristen, adalah gaya komunikasinya kepada jemaat. Gaya komunikasi, menurut pengertiannya adalah seperangkat perilaku antarpribadi yang ter-spesialisasi digunakan dalam suatu situasi tertentu. Masing-masing gaya komunikasi, terdiri dari sekumpulan perilaku komunikasi yang digunakan untuk mendapatkan respon ataupun suatu tanggapan tertentu dalam situasi yang tertentu pula. Kesesuaian dari satu gaya komunikasi yang digunakan bergantung pada maksud dari sender dan harapan dari pihak receiver. (Suranto, 2011).

Seperti penjelasan sebelumnya, gaya komunikasi adalah salah satu hal yang perlu dijaga oleh seorang pemimpin jemaat gereja. Salah satu dampak dari dijaga nya gaya komunikasi yang baik adalah terciptanya loyalitas pada jemaat. Loyalitas, memiliki artian sebagai kesetiaan, pengabdian serta kepercayaan yang diberikan atau ditujukan kepada seseorang ataupun lembaga, yang didalamnya terdapat rasa cinta serta tanggung jawab untuk berusaha memberikan pelayanan dan perilaku yang terbaik. (Dikdik Subagja, 2018, p.44). Loyalitas menjadi suatu hal yang penting di dalam komunitas Kristen maupun gereja. Di Indonesia sering sekali dijumpai individu - individu yang tidak menetap atau loyal dengan satu kelompok gereja. Para individu ini cenderung berpindah - pindah gereja di setiap minggunya atau pada event tertentu. Dewasanya, hal ini biasa terjadi karena tidak adanya kesesuaian dengan individu tersebut, baik dalam hal komunikasi pemimpin gereja secara langsung kepada jemaatnya, sampai gaya komunikasi pemimpin gereja dalam penyampaian ceramah/khotbah di setiap sesinya. Berdasarkan kasus yang terjadi ini, penulis memiliki ke inginan untuk meneliti mengenai gaya komunikasi dari seorang pemimpin jemaat dalam membangun loyalitas jemaat nya.

Pada penelitian ini, penulis memilih Ps. Jahja Gani, sebagai pemimpin jemaat yang dipilih untuk diteliti, guna melihat dan mengetahui gaya komunikasi nya dalam membangun loyalitas jemaat. Ps. Jahja Gani adalah pemimpin jemaat dari gereja Every Nation Jakarta. Gereja ini terletak di daerah Kuningan, Jakarta Selatan. Sudah berdiri lebih dari 20 tahun, saat ini gereja tersebut memiliki cabang di 14 kota di Indonesia. Every Nation Jakarta sendiri, saat ini memiliki kurang lebih 450 jemaat di dalamnya (cabang Kuningan, Jakarta Selatan). Di dalam kepemimpinannya, Ps. Jahja Gani memiliki 4 orang pendeta yang berada dibawah kepemimpinannya, yang ditugaskan berdasarkan fungsi struktural dan departemennya masing - masing. Alasan dipilihnya tempat ini serta Ps. Jahja Gani menjadi objek dari penelitian ini, adalah dikarenakan keunikan dari struktural kepemimpinan yang ada di gereja ini, serta lama berdirinya gereja ini dinilai sudah melewati banyak pengalaman dalam membangun loyalitas di dalam jemaatnya. Rumusan masalah yang digunakan dalam penelitian ini adalah, bagaimana gaya komunikasi pemimpin jemaat Every Nation Jakarta dalam membangun loyalitas pada jemaatnya. Tujuan dari penelitian ini, adalah mengetahui secara langsung gaya komunikasi dari Ps. Jahja Gani dalam membangun loyalitas jemaatnya, serta mengetahui juga sudut pandang dari jemaat mengenai gaya komunikasi dari Ps. Jahja gani. Penulis, dalam penelitian ini mengambil contoh penelitian terdahulu untuk mendukung serta memberi referensi lebih mengenai penelitian ini. Salah satunya adalah penelitian milik Priskila Cayadi (2016), dari Universitas Kristen Petra Surabaya yang berjudul "Gaya Komunikasi 
Pemimpin Gereja Sidang Jemaat Kristus Subabaya". Dari penelitian tersebut, penulis mendapatkan banyak referensi dengan adanya teori dan objek yang sama yaitu mengenai gaya komunikasi dalam lingkup pemimpin suatu gereja. Selain itu, penelitian terdahulu lainnya yang menjadi referensi adalah penelitian milik Evelyn dan H.H. Daniel Tamburian (2018) yang berjudul "Gaya Komunikasi Pemilik Restoran Vegetus Vegetarian dalam Membangun Motivasi Kerja Karyawan". Penelitian milik mahasiswa dan dosen Universitas Tarumanagara ini banyak memberikan referensi juga mengenai kepemimpinan. Berdasarkan latar belakang, rumusan masalah, tujuan, hingga penelitian terdahulu diatas, penulis menetapkan untuk menuangkan penelitian ini dalam judul "Gaya Komunikasi Pemimpin Jemaat Gereja Every Nation Jakarta Dalam Membangun Loyalitas Jemaat”.

\section{Metode Penelitian}

Dalam penelitian ini, penulis menggunakan pendekatan penelitian kualitatif dengan metode studi kasus. Penelitian kualitatif menurut Ali dan Yusof (2011) pada artikel milik Kementrian keuangan, memiliki pengertian sebagai 'Any investigation which does not make use of statistical procedures is called "qualitative" nowdays, as if this were a quality label in itself'. Dari hal ini Ali dan Yusof menekankan pada ketidak hadirannya alat - alat statistic yang digunaka dalam penelitian kualitatif. Dalam artikel yang sama, disebutkan, Basri (2014) mengatakan, fokus dari suatu metode penelitian kualitatif terletak pada prosesnya dan dari pemaknaan hasil penelitiannya.(sumber

http://www.djkn.kemenkeu.go.id/artikel/baca/12773/Memahami-Metode-PenelitianKualitatif.html diakses pada 12 April 2020 pukul 23.02 WIB). Pengertian lainnya menyebutkan, sifat atau karakteristik dari pendekatan kualitatif adalah penekanan pada lingkungan yang alamiah (naturalisticsetfing), induktif (inductive), fleksibel (flexible), pengalaman langsung (direct experience), kedalaman (indepth), proses, menangkap arti (Verstehen), keseluruhan (wholeness), partisipasi aktif dari partisipan dan penafsiran (interpretation). (J. R. Raco, 2010, p.56).

Pada penelitian ini, selain menggunakan observasi, dokumentasi serta studi kepustakaan, penulis juga melakukan wawancara kepada 3 (tiga) narasumber yang berasal dari jemaat gereja Every Nation Jakarta, yaitu Ps. John Kullit, Justin Tjoandi, dan Nesya Manurung sebagai metode pengumpulan data. Analisis data, pada penelitian ini akan menggunakan cara menurut penjelasan pada penelitian Ade Novianti (2017), yaitu dengan melalui proses Reduksi data, display data (penyajian data), dan verifikasi data (kesimpulan data). (Ade Novianti, 2017, p.49-50).

\section{Hasil Temuan dan Diskusi}

Gaya komunikasi dari pastor Jahja Gani dalam membangun loyalitas jemat, penemuan sifat kepemimpinan beliau yang mendukungnya dalam melakukan gaya komunikasi, serta perilaku yang dilakukannya kepada jemaat guna membangun loyalitas pada jemaat, terutama pada masa COVID-19 saat ini.

Ditemukan dua gaya komunikasi yang menggambarkan Ps. Jahja Gani dalam membangun komunikasinya dengan jemaatnya yaitu, gaya komunikasi berlandaskan kesamaan (The Equalitarian Style), gaya komunikasi melepaskan hak memberi perintah (The Relinguishing Style). Menurut Steward L. Tubbs dan Sylvia Moss 
dalam jurnal milik Ella Damayanti (2018) menjelaskan definisi dari kedua gaya komunikasi tersebut, yaitu :

\section{Gaya komunikasi berlandaskan kesamaan (The Equalitarian Style)}

Adalah gaya komunikasi dua arah yang berlandaskan oleh aspek kesamaan. Ciri khas gaya ini adalah adanya arus komunikasi timbal balik. Dalam hal ini komunikasi cenderung dilakukan secara terbuka. (Ella Damayanti, 2018, p.263). Berdasarkan penemuan di lapangan, hal ini dinilai sebagai gaya komunikasi yang digunakan oleh Ps. Jahja Gani dikarenakan menurut para pandangan narasumber kepedulian tinggi, membuka diri untuk diskusi dengan siapapun, keramahan, dan mampu beradaptasi dengan siapapun, adalah gaya komunikasi yang ditunjukkan oleh Ps. Jahja Gani kepadanya jemaatnya.

\section{Gaya komunikasi melepaskan hak memberi perintah (The Relinguishing Style)}

Memiliki definisi sebagai gaya komunikasi yang lebih mencerminkan terhadap kesedian menerima saran, pendapat maupun gagasan orang lain, dibandingkan dengan keinginan untuk memberi perintah, meskipun pengiriman pesan (sender) mempunyai hak untuk memberi perintah dan mengontrol orang lain. (Ella Damayanti, 2018, p.264). Berdasarkan penemuan dilapangan melalui wawancara, menurut para narasumber, Ps Jahja Gani adalah pribadi yang mau mendengarkan saran, pendapat, serta gagasan dari semua pihak. Selain itu, beliau adalah pribadi yang memberikan kepercayaan kepada jemaat, bahkan sedikit banyak lebih memberikan ruang untuk para jemaat ber-ekspresi dengan apa yang menjadi gagasan mereka. Dalam hal masukan maupun saran, Ps. Jahja Gani menunjukkan sikapnya yang tidak tersinggung kepada jemaat. Beliau tidak menggunakan kepemimpinannya untuk mengontrol berbagai pihak.

berdasarkan penemuan di lapangan, para narasumber pun berpendapat, bahwasannya gaya komunikasi yang digunakan oleh Ps. Jahja Gani sudah tepat dengan situasi kondisi yang berada di jemaat. Mereka berpendapat, gaya komunikasi ini sudah berhasil membangun loyalitas jemaat gereja Every Nation Jakarta, terutama se masa melewati krisis transisi beberapa tahun silam.

Dalam gaya komunikasi Ps. Jahja Gani yang digunakan untuk membangun loyalitas jemaat, tentunya didukung juga dengan sifat pemimpin yang secara pribadi dimiliki oleh Ps. Jahja Gani. Menurut penelitian milik Sriwidadi (2011), terdapat 10 sifat pemimpin, yaitu: (1) energi jasmaniah dan mental (physical and nervous energy); (2) kesadaran akan tujuan dan arah (a sense of purpose and direction); (3) antusiasme (enthusiasm; semangat, kegairahan, kegembiraan yang besar); (4) keramahan dan kecintaan (friendliness and affection); (5) integritas (integrity, keutuhan, kejujuran, ketulusan hati); (6) penguasaan teknis (technical mastery); (7) ketegasan dalam mengambil keputusan (decisiveness); (8) kecerdasan (intelligence); (9) keterampilan mengajar (teaching skill); (10) kepercayaan (faith). (Sriwidadi, 2011, p.389).

Dari kesepuluh sifat tersebut, menurut data yang didapatkan melalui wawancara dengan para narasumber, Ps Jahja Gani memiliki 5 (lima) sifat yang menggambarkan beliau, dalam menjalankan kepemimpinannya, yaitu: kepercayaan (faith), ketegasan dalam mengambil keputusan (decisiveness), integritas (integrity, keutuhan, kejujuran, ketulusan hati), keramahan dan kecintaan (friendliness and affection), dan antusiasme (enthusiasm; semangat, kegairahan, kegembiraan yang 
besar). Hal ini dinyatakan sebagai sifat pemimpin yang dimiliki oleh pribadi Ps. Jahja Gani, dikarenakan pembawaan beliau yang secara natural memberikan kepercayaan penuh kepada seseorang, menunjukkan ketegasan dalam mengambil keputusan namun tetap bijaksana, menunjukkan ketulusan hati, kejujuran, serta sifat yang tidak memikirkan keuntungan pribadi, memberikan keramahannya dan kepeduliannya, dan selalu menunjukkan antusiasme dan semangatnya kepada jemaat di dalam segala situasi yang membuat jemaat lebih bergairah untuk terus ada memberikan diri mereka untuk loyal kepada gereja Every Nation Jakarta.

Pada masa pandemi COVID-19, meskipun gedung gereja Every Nation Jakarta harus tutup seperti anjuran dari pemerintah Republik Indonesia dalam rangka mengurangi penyebaran penyakit, Ps. Jahja Gani tetap menunjukkan konsistensinya dalam membangun loyalitas dalam jemaat. Berdasarkan obeservasi yang dilakukan oleh penulis, hal ini ditunjukkan dengan berbagai kebijakan yang beliau berikan dan terapkan yang sesuai dengan keperluan jemaat, seperti dilaksanakan dan diberlakukannya ibadah daring, tetap dilaksanakannya pertemuan dengan jemaat Lifegroup Leader melalui pertemuan dari di media sosial ZOOM, hingga diterapkannya ruangan doa daring melalui media sosial Zoom yang difungsikan beliau untuk bertemu jemaat setelah ibadah daring mingguan, terutama bagi para jemaat yang ingin di doakan oleh Ps Jahja Gani dan tim pastoral nya. Selama ibadah daring di masa pandemi COVID-19 ini, Pastor Jahja Gani juga tetap menunjukkan pengabdiannya kepada gereja dan jemaat, hal ini ditunjukkan dengan beliau memimpin secara langsung seluruh khotbah mingguan yang diadakan di ibadah daring gereja Every Nation Jakarta selama masa pandemi COVID-19 ini berlangsung.

\section{Simpulan}

Berdasarkan hasil penelitian yang dilakukan penulis mengenai gaya komunikasi Ps. Jahja Gani dalam membangun loyalitas jemaat gereja Every Nation Jakarta, penulis menyimpulkan, gaya komunikasi yang digunakan oleh Ps. Jahja Gani adalah gaya komunikasi berlandaskan kesamaan (the equalitarian style), dan juga gaya komunikasi melepaskan hak memberi perintah (the relinguishing style). Gaya komunikasi yang digunakan dinilai sudah tepat dengan kondisi situasi pada jemaat gereja Every Nation Jakarta, serta sudah dapat dikatakan berhasil dalam membangun loyalitas jemaat.

Sifat kepemimpinan yang dimiliki oleh Ps. Jahja Gani, yang mencakup kepercayaan, ketegasan dalam mengambil keputusan, integritas (keutuhan, kejujuran, ketulusan hati), keramahan dan kecintaan, dan antusiasme (semangat, kegairahan, kegembiraan yang besar) juga sudah terlihat membantu usaha Ps. Jahja Gani dalam membangun loyalitas di dalam jemaat. Dalam hal ini, Ps. Jahja Gani, sudah mendapat bagiannya tersendiri di mata para individu di gereja Every Nation Jakarta, terutama di mata para narasumber seperti Ps, John Kullit, Justin Tjoandi, dan Nesya Manurung, pastor Jahja sudah sangat meninggalkan kesan positif yang mendalam di hidup mereka.

Selama masa pandemi COVID-19 ini, Ps. Jahja Gani dinilai sudah banyak melakukan hal - hal yang berguna untuk membangun dan menjaga loyalitas di jemaat. Ibadah daring hingga ruang doa daring dilakukan oleh pastor Jahja guna tetap berinteraksi serta menjaga loyalitas mereka. Jadi, dapat dikatakan, semua cara yang sudah dan sedang dilakukan oleh Ps. Jahja Gani dinilai sesuai, namun tetap 
diperlukan pengembangan diri dan penyesuaian lebih terhadap segala situasi kondisi, guna dimilikinya keseimbangan yang dirasakan oleh jemaat.

\section{Ucapan Terima Kasih}

Pada penelitian ini, penulis mengucapkan banyak terima kasih kepada Fakultas Ilmu Komunikasi Universitas Tarumanagara sebagai tempat penulis menimba ilmu, kepada para narasumber yang telah memberikan segala informasi yang terkait dengan penelitian ini. Lalu penulis juga memberikan rasa terima kasih secara penuh kepada seluruh keluarga, kerabat, sahabat, serta teman - teman penulis yang turut membantu dengan berbagai cara dalam mendukung penulisan penelitian ini.

\section{Daftar Pustaka}

Suranto. (2011). Komunikasi Interpersonal. Jakarta: Graha Ilmu

Cayadi, Priskila. (2016). Gaya Komunikasi Pemimpin Gereja Sidang Jemaat Kristus Subabaya. Jurnal E-Komunikasi. Vol 4. No.1. Maret 26, 2020. Terarsip di: https:/www.neliti.com/publications/80927/gaya-komunikasi-pemimpingereja-sidang-jemaat-kristus-subabaya

Damayanti, Ella. (2018). Analisis Terhadap Gaya Komunikasi Kepala Desa Jemparing Di Kecamatan Long Ikis Kabupaten Paser. eJournal Ilmu Komunikasi, 6 (1), 258-270. April 10, 2020. Terarsip di : https://ejournal.ilkom.fisip-unmul.ac.id/site/wpcontent/uploads/2018/02/Jurnal\%20(02-13-18-02-19-51).pdf

Direktorat Jenderal Kekayaan Negara Kementrian Keuangan. (2019). Memahami Metode Penelitian Kualitatif. April 12, 2020. http://www.djkn.kemenkeu.go.id/artikel/baca/12773/Memahami-MetodePenelitian-Kualitatif.html

Evelyn \& Tamburian, H.H. (2018). Gaya Komunikasi Pemilik Restoran Vegetus Vegetarian dalam Membangun Motivasi Kerja Karyawan. Koneksi, Vol. 2, No. 2, 329-336. April 7, 2020. Terarsip: https://journal.untar.ac.id/index.php/koneksi/article/view/3903/2289

Novianti, Ade. (2017). Pola Dan Jaringan Komunikasi Tentang Pengangkatan Anak Secara Adat Pepadun Di Kabupaten Lampung Tengah (Studi Pada Kelompok Adat Di Pekon Way Buyut Lampung Tengah). April 15, 2020. http://digilib.unila.ac.id/28938/

Raco, J.R. (2010). Metode penelitian kualitatif: jenis, karakteristik dan keunggulannya. Jakarta: PT Grasindo

Sriwidadi, Teguh. (2011). Analisis Pengaruh Gaya Kepemimpinan Terhadap Kinerja SPG PD. Sumber Jaya. Binus Business Review, Vol 2, No 1. April 9, 2020. Terarsip di https://journal.binus.ac.id/index.php/BBR/article/view/1145/1012

Subagja, Dikdik. (2018). Gaya Komunikasi Ketua Sakamichi squad Bandung (Ssb) Dalam Meningkatkan Loyalitas Anggotanya (Studi Deskriptif mengenai Gaya Komunikasi Ketua Sakamichi Squad Bandung Dalam Meningkatkan Loyalitas Anggotanya). Elibrary Unikom. April 15, 2020. Terarsip di : https://elibrary.unikom.ac.id/id/eprint/343/ 